\title{
COVID-19: Crónica de una Infodemia. La segunda pandemia
}

\section{COVID-19: Chronicle of an infodemic. The second pandemic}

\author{
Rosana del V. Gaitán Russoa \\ a Dpto. Observatorio de Entidades de Comunicación, Consejo Profesional de Comunicación Social, Argentina
}

$\mathrm{L}$ a necesidad de información en tiempo real nunca ha sido tan apreciada como hoy en día. El minuto a minuto cuenta y convierte a los sucesos en materia prima fundamental para la comunicación en situación de crisis y desastres.

La dinámica de la información a través de los medios de comunicación, desde que las noticias de la existencia de un terrible virus comenzaron a diseminarse por el mundo, fue mutando día a día hasta encontrarse en el núcleo mismo del mal informativo.

El virus, que fue identificado por científicos chinos como SARS-CoV-2 por su relación con el SARS (Síndrome Respiratorio Agudo Severo), fue denominado Coronavirus COVID-19. Los coronavirus son una gran familia de virus que en general son inofensivos para los humanos pero que algunos de ellos causan enfermedades graves. En el caso del COVID-19, el virus ataca las células del sistema respiratorio causando malestar general, fiebre, tos y, en etapas más avanzadas, neumonía y disnea pudiendo también ocasionar la muerte. Además, posee un alto nivel de contagio a través de las gotas que salen por la boca o la nariz y que se depositan en cualquier superficie, hecho que lo hace también muy contagioso.

Por todas estas características nuevas, el virus se convirtió en el centro informativo de todos los medios de comunicación del mundo. Con un trayecto espiralado y en virulento aumento exponencial, la información fue poco a poco contaminando los medios informativos y las redes sociales hasta convertirse en otro gran mal.

La grave tragedia mundial ocasionada por el COVID-19 y la Infodemic, fueron y son dos males fundamentales que atacaron a las personas, las vulneraron y produjeron su muerte, en muchos casos.

Tedros Adhanom Ghebreyesus, Director General de la Organización Mundial de la Salud (OMS), comentó: "la infodemia está obstaculizando las medidas de contención del brote, provocando pánico y confusión de forma innecesaria y generando división en un momento en el que necesitamos ser solidarios y colaborar para salvar vidas y para poner fin a esta crisis sanitaria" (Ghebreyesus \& Ng, 2020).
Este hecho propicia un efecto de vulnerabilidad respecto a qué información es veraz y qué no lo es. En Argentina se usa este acrónimo españolizado como "infodemia", relacionándolo perfectamente con la "información en pandemia" que es profusa y confusa. Esta infodemia, fue un hecho que se sumó a la principal preocupación de las personas que fue la alta posibilidad de contagiarse con el virus que día tras día sumaba miles de fallecidos por esta enfermedad.

Desde mediados de febrero, aproximadamente, comenzó una escalada informativa sin precedentes. Los medios fueron adaptándose y recibiendo información de todo tipo. Cientos de noticias iban copando la televisión, la radio y las redes sociales con una velocidad nunca vista hasta el momento. No había tiempo para procesar la información. Debía ser instantánea y con una necesidad extraordinaria de un periodismo que aportara sentido a la "avalancha informativa" (Meseguer, 2018).

Esta especie de metamorfosis informativa tuvo que ver con varios factores que se podrían relacionar con: el desconocimiento de los alcances de una pandemia mundial de la envergadura del COVID-19, la falta de información científica y la falta de datos fidedignos, entre otros factores.

La preocupación de la comunidad científica también fue un hecho angustiante para las grandes audiencias, ya que la medicina carecía de evidencia científica concreta por tratarse de un virus desconocido. En el momento no existía un tratamiento específico para afrontar esta cepa vírica. Los periodistas también fueron aprendiendo en el día a día cómo abordar el tema sanitario. La situación de desconocimiento y escasez de información veraz posibilitó una dinámica vacía de contenido y por momentos adictiva. Fuimos espectadores de largos debates televisivos sobre el COVID-19, en los que muchas veces los protagonistas eran actores, astrólogos, modelos, políticos, filósofos, empresarios, etc... De este modo, se producía un desborde de información que se sumaba a todo lo que minuto a minuto fluía y resonaba en las redes sociales. Toda esta dinámica se daba en 
el marco de un rápido y creciente número de víctimas que se generaba en todo el mundo y que iba produciendo una situación de angustia e incertidumbre a medida que avanzaba la pandemia. Una gran crisis sanitaria estaba en ciernes y la desinformación aumentaba sus efectos.

Twitter, Instagram, Facebook, Whatsapp y algunas otras vías de comunicación utilizada por los cibernautas, se incendiaban con información de todo tipo. Miles de noticias de fuentes sospechosas, mezcladas con aquellas otras que surgían de la percepción propia de las personas, sobreinformaban mal a cada momento. Una gran cantidad de esa información era percibida por los usuarios de maneras distintas. La pandemia mundial era relacionada con la mística, con preceptos de la nueva era, con la política internacional, con los efectos de la economía globalizante, con un genocidio encubierto, con limpieza planetaria, con la justicia divina o con el castigo terrenal, entre otros tantos títulos. Cientos de videos falsos se volvieron virales por las redes, descubriendo más tarde que se trataba de las famosas fake news, 0 información falsa, en épocas de pandemia.

En toda esta vorágine informativa, se pudo observar la utilización continua y profusa de algunos términos polisémicos. Todos ellos utilizados por los autores de la información, propiciaron un malestar generalizado en las personas. La sociedad no solo pasaba a estar confinada, sino que además, tenía la necesidad abrumadora de informarse certeramente sobre el nuevo virus para evitar los efectos que traía la incertidumbre.

Para ejemplificar lo comentado, en un principio se comenzó a denominar el COVID-19 como "virus de los ricos", frase que rápidamente se apropiaron los medios de comunicación. Los usuarios de las redes sociales percibieron que era un virus que atacaba solo a aquellas personas con alto poder adquisitivo que tenían posibilidad de viajar al exterior, ya que en un principio fueron los turistas quienes transportaban el virus por todo el mundo. Luego se supo que cualquier persona podría haberse infectado en cualquier momento y en cualquier lugar, porque se trataba de un virus cuya característica principal era su alto nivel de contagio a través de las gotitas de Flügg. Al poco tiempo, y dada la escalada de muertos en China e Italia, esta percepción comenzó a desvanecerse, siendo reemplazada por una frenética búsqueda de fuentes informativas.

Mientras tanto, miles de personas fueron estigmatizadas con términos como: "caso sospechoso", "portador de Coronavirus COVID-19", "portador con enfermedad de base", entre otros. Los adultos mayores fueron los principales señalados por ser población de riesgo. En algunos países la situación fue tan grave que el personal médico tuvo que elegir entre colocar el respirador a un anciano o a una persona más joven, siendo ésta última la beneficiada. También, se llegó a colocar el mote de "bombas de tiempo" a las residencias geriátricas 0 centros de mayores que sufrieron intensamente los embates del virus, y ese término fue utilizado frecuentemente en los medios de comunicación.

Un detalle interesante al respecto es el del circunstancial de tiempo "ya", introducido en todos y cada uno de los reportes de los programas informativos sobre personas fallecidas. Este hecho, aunque no percibido por todos, impactó fuertemente en la salud psíquica y física de la gente que recibía mensajes como: "Ya son 300 las víctimas", "ya son 1000 los fallecidos", "ya superan los 1000 muertos".

Según la Nueva Gramática de la Lengua Española (2009), el adverbio "ya" denota que para interpretarlo se requiere de una fase previa o posterior a la de la situación descrita. Sin embargo, también puede tener un valor incoativo. Según la Real Academia Española (2001), el término incoativo implica o denota el principio de una cosa o de una acción progresiva. Si tomamos este último significado: "acción progresiva", aplicado a: "ya son X los muertos por Coronavirus", denota que no solo estaban vivos y dejaron de estarlo por el ataque del virus, sino que además, daba una idea de continuidad muy cruel, la gente iba a seguir muriendo. No es de extrañar que esta manera de nombrar las situaciones provocó en las personas un altísimo estrés y angustia, y esta situación actuó como un disparador de otras patologías predisponentes.

Lamentablemente el número de muertos informado a cada momento indicaba el progreso del virus en un lugar determinado. Es decir, los términos numéricos eran el dato más absoluto e insustituible para entender la Pandemia por el COVID-19.

Nada estaba claro en la información suministrada. Se estaba aprendiendo a informar y a informarse a medida que los eventos acontecían. Los usuarios, por su parte, fueron entendiendo que la información de las redes sociales no era en su mayoría fidedigna. Se fue aprendiendo, además, a utilizar buscadores específicos y consultar información científica. También se comenzó a dar un proceso de selección de canales que abordaban seriamente el tema y evitaban los shows mediáticos, se fue reflexionando sobre el impacto de las noticias virales de fuentes dudosas. El \#quedate en casa, no salgas, nos cuidamos entre todos, caló hondo. Se fue aprendiendo sobre la marcha. Responsabilidad informativa, le llaman.

Si bien este tiempo de pandemia es un tiempo 
de aprendizaje para todas las personas en distintas dimensiones, es importante reconocer que la comunicación tiene el poder de cambiar el orden de las cosas y de propiciar situaciones que impacten positivamente en la vida de las personas. No solo el COVID-19 estaba amenazando seriamente la vida de las personas, sino que un virus informativo anómalo y destructor minaba los entornos provocando males insospechados.

Han pasado ya casi dos meses del confinamiento preventivo y obligatorio en Argentina. No es fácil, ni lo será, determinar a corto o mediano plazo el impacto en la salud que tanta información-desinformación, sumado al uso de términos inconvenientes, han provocado en las personas. El proceso está en marcha.

\section{Referencias bibliográficas}

Ghebreyesus, T.A., \& Ng, A. (2020, 18 de febrero). Desinformación frente a medicina: hagamos frente a la 'infodemia'. El País. Recuperado de https://elpais.com/ sociedad/2020/02/18/actualidad/1582053544_191857. $\mathrm{html}$

Meseguer, J. (2018, 30 de enero). Un periodismo que aporte sentido en la avalancha informativa. Aceprensa. Recuperado de: https://www.aceprensa. com/articles/un-periodismo-que-aporte-sentido-enla-avalancha-informativa/

Real Academia Española. (2001). Diccionario de la Lengua Española (22.a ed.). Recuperado de https://www.rae.es/drae2001/incoativo 